\title{
Kemampuan Prediktif Laba dan Arus Kas Operasi Pasca Konvergensi IFRS
}

\author{
Andi Zulfakar Yudha \\ Universitas Fajar \\ yudhaps.hk@gmail.com \\ (Diterima: 24-Desember-2019; dipublikasikan: 31-Januari-2020)
}

\begin{abstract}
The objective of various accounting methods is to presenting the financial information which has relevant and reliable values to be usefull for their users. The research aimed to answer two crucial issues in accounting literature, i.e. predictive ability of earnings and operation cash flow on future operation cash flow and the impact of IFRS convergence on the information quality of financial report. The two issues were studied simultaneously.The research was conducted in manufacturing companies listed in Indonesia Stock Exchange from 2010 to 2013. The data were selected using purposive sampling method consisting of 56 companies which met the criteria with 122 years observation. The data were analyzed using quantitative approach through multiple regression analysis. The results of the research indicate that earnings and operation cash flow can predict operation cash flow within one year either before or after the IFRS convergence done. The ability even increases after IFRS convergence conducted. Current earnings empirically prove predictive ability which is better than current operation cash flow in predicting future operation cash flow. This empirical result is better for the periods either before and after convergence was done.
\end{abstract}

Keywords: Predictive ability; Standard, IFRS; Information quality; Relevance

\begin{abstract}
Abstrak
Tujuan dari berbagai pilihan metode akuntansi ialah menyediakan informasi keuangan yang bernilai relevan dan handal agar dapat bermanfaat bagi para pemakainya.Penelitian ini bertujuan menjawab dua isu krusial dalam literatur akuntansi, yaitu isu kemampuan prediktif laba dan arus kas operasi terhadap arus kas operasi masa depan dan isu dampak konvergensi IFRS terhadap kualitas informasi laporan keuangan. Penelitian dilaksanakan di perusahaan manufaktur yang terdaftar di Bursa Efek Indonesia dari tahun 2010 sampai dengan 2013. Pengumpulan data menggunakan metode sampel purposif. Terdapat 56 perusahaan yang memenuhi kriteria dengan jumlah pengamatan sebanyak 122 tahun pengamatan. Data dianalisis dengan pendekatan kuantitatif melalui teknik analisis regresi berganda. Hasil penelitian menunjukkan bahwa laba dan arus kas operasi mampu memprediksi arus kas operasi satu tahun ke depan, baik untuk periode sebelum maupun setelah dilakukannya konvergensi IFRS. Kemampuan tersebut bahkan meningkat setelah dilakukannya konvergensi IFRS. Laba tahun berjalan terbukti secara empiris memiliki kemampuan prediktif yang lebih baik daripada arus kas operasi tahun berjalan dalam memprediksi arus kas operasi masa depan. Hasil empiris tersebut berlaku, baik untuk periode sebelum maupun setelah dilakukannya konvergensi.
\end{abstract}

Kata kunci: Kemampuan prediktif; Standar, IFRS; Kualias informasi; Relevansi 


\section{PENDAHULUAN}

Hakikat dari eksistensi ilmu akuntansi adalah sebagai media penyedia informasi. Informasi akuntansi diwujudkan ke dalam serangkaian laporan keuangan yang diterbitkan sebuah perusahaan. Decision-usefulness theory menyatakan bahwa suatu informasi akuntansi harus memenuhi karakteristik kualitatif tertentu untuk dapat memberikan manfaat bagi para penggunanya dalam mengambil keputusan (Staubus, 1999). Demi mencapai tujuan penyajian laporan keuangan, maka suatu informasi akuntansi harus memenuhi karakteristik kualitatif tertentu. Godfrey et al (2010), menyatakan bahwa salah satu karakteristik informasi akuntansi yang bersifat primer ialah karakteristik relevansi. Relevansi adalah kualitas kemampuan informasi akuntansi untuk memenuhi tujuan laporan keuangan dalam proses pengambilan keputusan. Karakteristik ini membantu memberi nilai tambah bagi para pengguna laporan keuangan melalui predictive value, feedback value, dan timeliness. Nilai prediktif merupakan salah satu fokus utama pada penelitian ini.

Kualitas informasi yang diangkat pada penelitian ini ialah kualitas relevansi. Salah satu elemen dari kualitas relevansi informasi ialah nilai prediktif (predictive value) dari suatu informasi. Saat ini telah cukup banyak penelitian yang mengkaji isu kemampuan prediktif laba dan arus kas operasi. Hasil penelitian Dechow et al (1997), Kim \& Kross (2005), Watson \& Wells (2005), Pouraghajan et al (2012), Shubita (2013), serta Takhtatei \& Karimi (2013), menyatakan bahwa laba memiliki kemampuan prediktif atas arus kas operasi masa depan yang lebih baik daripada arus kas operasi tahun berjalan. Sementara hasil penelitian Dahler \& Febrianto (2006), dan Joni (2011), menyatakan bahwa arus kas operasi tahun berjalan merupakan prediktor yang lebih baik dibandingkan laba dalam memprediksi arus kas operasi masa depan.

Pada sisi lain, isu mengenai dampak konvergensi IFRS kedalam standar akuntansi keuangan Indonesia menjadi fenomena yang patut untuk dikaji. Berbagai dalil mengenai manfaat dan segala argumen yang bersifat pro terhadap penerapan standar tersebut pun telah disahkan pemerintah. Salah satu alasan yang diajukan ialah pengaplikasian standar baru tersebut akan meningkatkan kualitas informasi akuntansi yang tersaji. Ball (2006), menyatakan bahwa IFRS menjanjikan informasi laporan keuangan yang lebih akurat, komprehensif, dan tepat waktu. Public interest theory menyatakan bahwa regulasi muncul sebagai respon terhadap permintaan publik untuk memperbaiki praktik-praktik pasar yang tidak efisien dan tidak adil. Asumsi yang didasarkan adalah bahwa regulasi muncul untuk memberikan manfaat bagi masyarakat secara keseluruhan dan bukan untuk kepentingan sekelompok golongan. Regulator muncul untuk merepresentasikan kepentingan publik dimana ia berada, dan bukan untuk kepentingan pribadi regulator tersebut (Pigou,1932). Fenomena konvergensi IFRS merupakan sebuah representasi intervensi pemerintah untuk memberikan perlindungan yang lebih baik bagi para pengguna output laporan keuangan yang disajikan oleh setiap entitas. Relevansi tujuan tersebut menjadi ranah kajian yang layak untuk diuji.

Perubahan standar yang dimandatkan oleh pemerintah diyakini dapat memberikan kualitas informasi akuntansi yang lebih baik. Petreski (2005), memaparkan bahwa peralihan tersebut dianggap lebih mampu mencerminkan keadaan perusahaan dengan lebih baik, lebih mampu melindungi pemakainya, dan lebih dapat memenuhi kebutuhan pasar. Beberapa penelitian empiris pun membuktikan kebenaran argumen Petreski (2005). Hasil penelitian Daske et al (2008), Houqe et al (2012), Lestari \& Takada (2010), Nuariyanti \& Erawati (2014), dan Laming (2014), menyatakan bahwa perubahan standar terbukti dapat meningkatkan kualitas informasi akuntansi yang tersaji. Sedangkan hasil penelitian Jeanjean \& Stolowy (2008), dan Cahyonowati \& Ratmono (2012), menemukan bahwa perubahan standar belum dapat meningkatkan kualitas informasi akuntansi yang tersaji.

Penelitian ini berusaha menghubungkan dua isu krusial dalam literatur akuntansi. Isu pertama adalah kualitas prediktif informasi akuntansi yang terkandung dalam laporan 
keuangan perusahaan. Isu kedua adalah dampak peralihan standar akuntansi keuangan dari PSAK berbasis GAAP menjadi PSAK berbasis IFRS terhadap kualitas informasi laporan keuangan yang tersaji. Kedua isu ini seringkali dikaji secara terpisah. Beberapa penelitian yang menguji kemampuan laba memprediksi arus kas operasi menghasilkan kesimpulan yang kontradiktif satu sama lain. Seperti halnya penelitian yang mengkaji dampak peralihan IFRS terhadap praktik akuntansi pasca peralihan tersebut pun menghasilkan kesimpulan yang saling bertentangan. Penelitian ini bertujuan untuk menemukan jawaban dari isu kemampuan prediktif laba dan arus kas operasi terhadap arus kas operasi masa depan pasca diterapkannya konvergensi IFRS.

\section{METODE PENELITIAN}

Penelitian dilakukan pada Bursa Efek Indonesia (BEI) menggunakan teknik dokumentasi. Data yang dikumpulkan berupa laporan keuangan tahunan perusahaan yang terdaftar di BEI. Penelitian ini bersifat basic research dengan pendekatan kuantitatif. Tujuan penelitian ini bersifat hypotheses testing dengan menggunakan desain longitudinal study.

Populasi penelitian ini adalah seluruh perusahaan manufaktur yang terdaftar di BEI dari tahun 2010 s/d 2013. Pemilihan sampel dilakukan dengan metode purposive sampling. Perusahaan yang dipilih merupakan perusahaan yang menerbitkan laporan keuangannya secara lengkap dari tahun $2010 \mathrm{~s} / \mathrm{d}$ 2013. Hasil seleksi sampel diperoleh 56 perusahaan dengan total tahun pengamatan sebanyak 112 tahun pengamatan.

Data yang dikumpulkan berupa data kuantitatif yang diperoleh menggunakan metode dokumentasi. Sumber data penelitian ini merupakan sumber data sekunder berupa laporan keuangan tahunan perusahaan yang dipublikasikan melalui situs resmi Bursa Efek Indonesia. Data untuk representasi dari variabel dependen arus kas operasi masa depan diperoleh dari angka arus kas operasi yang tertera pada laporan arus kas untuk tahun yang diprediksi. Data untuk representasi dari variabel independen laba tahun berjalan diperoleh dari angka laba bersih yang tertera pada laporan laba rugi untuk tahun yang memprediksi. Data untuk representasi dari variabel independen arus kas operasi tahun berjalan diperoleh dari angka arus kas operasi yang tertera di laporan arus kas untuk tahun yang memprediksi. Zhao et al (2007), menyatakan bahwa angka-angka laporan keuangan merupakan hasil dari berbagai pilihan metode akuntansi berdasarkan standar akuntansi yang digunakan. Asumsi ini mendasari pemilihan ukuran-ukuran variabel pada penelitian ini.

Penelitian ini menggunakan model empiris yang telah digunakan pada penelitian sebelumnya. Model yang digunakan dalam penelitian ini adalah gabungan earnings model dan $C F O$ model yang digunakan Kim \& Kross (2005) dan Dahler \& Febrianto (2006). Model regresi dalam penelitian ini ditunjukkan dalam persamaan-persamaan berikut:

$$
\begin{aligned}
& \mathrm{CFO}_{i t+1}=\alpha_{0}+\alpha_{1} E_{i t}+\alpha_{2} \mathrm{CFO}_{i t}+i t \\
& \text {.......................... } \\
& C F O_{i t+1}=\beta_{0}+\beta_{1} E_{i t}+\beta_{2} C F O_{i t}+i t
\end{aligned}
$$

dimana:

$$
\begin{aligned}
& \boldsymbol{C F} \boldsymbol{O}_{i t+1}=\text { arus kas operasi perusahaan } I \text { pada } \\
& \text { tahun } t+1 \text {; } \\
& \boldsymbol{\alpha}_{\boldsymbol{0}} \quad=\text { koefisien konstanta periode sebe- } \\
& \text { lum konvergensi IFRS; } \\
& \alpha_{1}, \alpha_{2}=\text { koefisien variabel independen pe- } \\
& \text { riode sebelum konvergensi IFRS; } \\
& \boldsymbol{\beta}_{0}=\text { koefisien konstanta untuk periode } \\
& \text { setelah konvergensi IFRS; } \\
& \boldsymbol{\beta}_{1,} \boldsymbol{\beta}_{2}=\text { koefisien variabel independen un- } \\
& \text { tuk periode setelah konvergensi } \\
& \text { IFRS; } \\
& \boldsymbol{E}_{i t} \quad=\text { laba sebelum pos-pos luar biasa } \\
& \text { perusahaan } i \text { pada tahun } t \text {; } \\
& \boldsymbol{C F O}_{i t}=\text { arus kas operasi perusahaan } i \text { pada } \\
& \text { tahun } t \text {; } \\
& \text { it = variabel gangguan. }
\end{aligned}
$$

\section{HASIL DAN PEMBAHASAN}

Penelitian ini menemukan bahwa laba dan arus kas operasi mampu memprediksi 
arus kas operasi satu tahun ke depan, baik untuk periode sebelum maupun setelah dilakukannya konvergensi IFRS. Kemampuan tersebut bahkan meningkat setelah dilakukannya konvergensi IFRS. Laba tahun berjalan terbukti secara empiris memiliki kemampuan prediktif yang lebih baik daripada arus kas operasi tahun berjalan dalam memprediksi arus kas operasi masa depan. Kesimpulan tersebut berlaku baik untuk periode sebelum maupun setelah dilakukannya konvergensi. Seluruh hasil penelitian ini menunjukkan bahwa telah terjadi peningkatan kemampuan prediktif laba dan arus kas operasi pasca konvergensi IFRS.

Hasil uji regresi linier berganda atas model yang telah dibangun dapat dilihat pada Tabel 1 dan Tabel 2 berikut.

Tabel 1 Hasil Pengujian Regresi Linier Berganda Sebelum Konvergensi IFRS

\begin{tabular}{cccc}
\hline Variabel & Koefisien & t hitung & Sig. \\
\hline Konstanta & $148.793,4$ & 2,083 & 0,421 \\
$\mathrm{E}_{\text {it }}$ & 0,581 & 19,596 & 0,000 \\
$\mathrm{CFO}_{\text {it }}$ & 0,039 & 5,136 & 0,000
\end{tabular}

Adjusted R-square $=0,898$

F hitung $=243,606 ; \mathrm{Sig}=0,000$

(dalam juta rupiah)

Tabel 2 Hasil Pengujian Regresi Linier Berganda Setelah Konvergensi IFRS

\begin{tabular}{cccc}
\hline Variabel & Koefisien & t hitung & Sig. \\
\hline Konstanta & $-100.090,2$ & $-1,767$ & 0,083 \\
$\mathrm{E}_{\text {it }}$ & 0,743 & 24,966 & 0,000 \\
$\mathrm{CFO}_{\text {it }}$ & 0,438 & 8,719 & 0,000
\end{tabular}

Adjusted R-square $=0,984$

$\mathrm{F}$ hitung $=1682,915 ; \mathrm{Sig}=0,000$

(dalam juta rupiah)

Tabel 1 merupakan data hasil regresi untuk persamaan 1 . Pengujian tersebut dilakukan menggunakan kelompok data perusahaan untuk periode sebelum konvergensi IFRS. Pengujian untuk sampel tersebut menunjukkan bahwa model tersebut memiliki adjusted $R$ square sebesar $89,8 \%$. Pengujian hipotesis pertama menunjukkan bahwa untuk pengujian regresi secara parsial pada periode sebelum konvergensi IFRS terhadap laba tahun berjalan $\left(E_{i t}\right)$ ) diperoleh $t$ hitung sebesar 19,596 dengan nilai signifikansi sebesar 0,000 $(<0,05)$. Hal ini merupakan indikasi diterimanya hipotesis pertama. Pengujian hipotesis kedua menunjukkan bahwa untuk pengujian regresi secara parsial pada periode sebelum konvergensi IFRS terhadap arus kas operasi tahun berjalan $\left(\mathrm{CFO}_{\mathrm{it}}\right)$ diperoleh t hitung sebesar 24,966 dengan nilai signifikansi sebesar $0,000(<0,05)$. Hasil uji ini mengindikasikan bahwa hipotesis kedua diterima. Pengujian hipotesis ketiga dilakukan dengan melihat koefisien variabel-variabel independen dari hasil pengujian regresi linier sebelum periode konvergensi IFRS. Tabel 1 menunjukkan bahwa kedua variabel independen tersebut memiliki nilai signifikansi $0,000(<0,05)$. Hal ini bermakna bahwa keduanya dapat menjelaskan variabel dependen secara signifikan. Hasil yang diperoleh menunjukkan bahwa laba tahun berjalan $\left(\mathrm{E}_{\mathrm{it}}\right)$ memiliki koefisien sebesar 0,581. Nilai tersebut lebih besar jika dibandingkan dengan koefisien dari arus kas operasi tahun berjalan $\left(\mathrm{CFO}_{\mathrm{it}}\right)$ yaitu sebesar 0,039 . Hasil ini mengindikasikan bahwa hipotesis ketiga diterima.

Tabel 2 merupakan data hasil regresi untuk persamaan 2. Pengujian tersebut dilakukan menggunakan kelompok data perusahaan untuk periode setelah konvergensi IFRS. Pengujian untuk sampel tersebut model tersebut memiliki adjusted $R$ square sebesar 98,4\%. Pengujian regresi secara parsial pada periode setelah konvergensi IFRS terhadap laba tahun berjalan $\left(\mathrm{E}_{\mathrm{it}}\right)$ diperoleh $\mathrm{t}$ hitung sebesar 24,966 dengan nilai signifikansi sebesar 0,000 $(<0,05)$. Hal ini bermakna bahwa pada periode setelah konvergensi IFRS, laba tahun berjalan $\left(\mathrm{E}_{\mathrm{it}}\right)$ memiliki kemampuan untuk memprediksi arus kas operasi satu tahun ke depan $\left(\mathrm{CFO}_{\mathrm{it}+1}\right)$. Demi menjawab hipotesis keempat, maka koefisien regresi laba tahun berjalan $\left(\mathrm{E}_{\mathrm{it}}\right)$ pada periode sebelum dan sesudah konvergensi IFRS akan diperbandingkan. Hal ini dilakukan sebab berdasarkan hasil pengujian, keduanya dianggap mampu memprediksi arus kas satu tahun ke depan 
$\left(\mathrm{CFO}_{\mathrm{it}+1}\right)$. Pada periode sebelum konvergensi IFRS, nilai koefisien regresi laba tahun berjalan $\left(E_{i t}\right)$ sebesar 0,581. Nilai tersebut meningkat pada periode setelah konvergensi IFRS, yaitu menjadi 0,743 . Hasil pengujian ini mengindikasikan bahwa hipotesis keempat diterima. Pengujian regresi secara parsial pada periode setelah konvergensi IFRS terhadap arus kas operasi tahun berjalan $\left(\mathrm{CFO}_{\text {it }}\right)$ diperoleh $\mathrm{t}$ hitung sebesar 8,719 dengan nilai signifikansi sebesar $0,000(<0,05)$. Hasil ini bermakna bahwa pada periode setelah konvergensi IFRS, arus kas operasi tahun berjalan $\left(\mathrm{CFO}_{\text {it }}\right)$ memiliki kemampuan untuk memprediksi arus kas operasi satu tahun ke depan $\left(\mathrm{CFO}_{\mathrm{it}+1}\right)$. Pada periode sebelum konvergensi IFRS, nilai koefisien regresi arus kas tahun berjalan $\left(\mathrm{CFO}_{\mathrm{it}}\right)$ sebesar 0,039, nilai tersebut meningkat pada periode setelah konvergensi IFRS, yaitu menjadi 0,438 . Hasil perbandingan ini menyimpulkan bahwa hipotesis kelima diterima. Pengujian hipotesis keenam dilakukan dengan melihat koefisien variabelvariabel independen dari hasil pengujian regresi linier berganda setelah periode konvergensi IFRS. Tabel 2 menunjukkan bahwa kedua variabel independen ini memiliki nilai signifikansi $0,000 \quad(<0,05)$. Hasil yang diperoleh menunjukkan bahwa laba tahun berjalan $\left(E_{i t}\right)$ memiliki koefisien sebesar 0,743. Nilai tersebut lebih besar jika dibandingkan dengan koefisien dari arus kas operasi tahun berjalan $\left(\mathrm{CFO}_{\mathrm{it}}\right)$ yaitu sebesar 0,438. Hasil perbandingan tersebut mengindikasikan bahwa hipotesis keenam diterima.

Temuan-temuan empiris pada penelitian ini telah mengkonfirmasi hasil-hasil penelitian terdahulu. Hasil penelitian Dechow et al (1997), Kim \& Kross (2005), Watson \& Wells (2005), Pouraghajan et al (2012), Shubita (2013), serta Takhtatei \& Karimi (2013), menyatakan bahwa laba memiliki kemampuan prediktif atas arus kas operasi masa depan yang lebih baik daripada arus kas operasi tahun berjalan. Temuan empiris pada penelitian ini telah membenarkan pernyataan tersebut. Hasil penelitian Daske et al(2008), Hoque et al(2012), Lestari \& Takada (2010), Nuariyanti \& Erawati (2014), dan Laming (2014), menyatakan bahwa perubahan standar terbukti dapat meningkatkan kualitas informasi akuntansi yang tersaji. Temuan empiris pada penelitian ini pun turut membenarkan pernyataan tersebut.

Decision usefulness theory menyatakan bahwa tujuan dari akuntansi adalah menyediakan informasi mengenai sebuah perusahaan kepada para penggunanya dalam rangka pengambilan keputusan (Staubus, 1999). Salah satu indikator kualitas informasi adalah apabila ia memiliki kemampuan memprediksi keadaan dimasa mendatang. Dechow et al (1997), menyatakan bahwa laba menempati posisi yang sangat sentral dalam akuntansi. Laba merupakan ukuran ringkas akuntansi mengenai kinerja sebuah perusahaan. Kemampuan laba memprediksi arus kas operasi disebabkan oleh adanya komponen arus kas operasi selain daripada komponen-komponen akrual yang terkandung dalam angka laba.

Kemampuan arus kas operasi memprediksi arus kas operasi satu tahun ke depan merupakan representasi dari kualitas informasi yang disajikan oleh suatu standar. Kim \& Kross (2005), mengutip pernyataan FASB di tahun 1978 yang menyatakan bahwa "laporan keuangan harus menyediakan informasi yang membantu investor, kreditor, dan pihak lainnya untuk menilai waktu dan ketidakpastian arus kas prospektif atas perusahaan tersebut". Cheng \& Hollie (2005), menemukan beberapa hal penting. Pertama, bahwa arus kas terkait penjualan, harga pokok penjualan, beban operasi, dan bunga mampu memprediksi arus kas di masa depan dengan sangat baik. Kedua, arus kas terkait aktivitas lainnya mampu memprediksi arus kas di masa depan dengan cukup baik sekalipun tidak sebaik keempat komponen sebelumnya. Temuan-temuan ini telah menyiratkan adanya fakta mengenai informasi unsur arus kas. Cheng \& Hollie (2005), menyatakan bahwa sekalipun arus kas memiliki berbagai macam komponen yang dikandungnya, tetapi mayoritas komponennya terbukti mampu memprediksi arus kas masa depan dengan sangat baik, terutama arus kas operasi.

Selain itu, laba terbukti memiliki kemampuan prediktif yang lebih baik daripada arus kas operasi. Dechow et al(1997), menjelaskan 
bahwa superioritas laba dalam memprediksi arus kas operasi masa depan sangat berkaitan erat dengan siklus operasi perusahaan. Kemampuan laba menjadi lebih baik (daripada arus kas operasi) untuk perusahaan yang siklus operasinya meningkat. Sebaliknya, ketika perusahaan memiliki siklus operasi yang tidak meningkat, maka kemampuan laba dalam memprediksi arus kas operasi satu tahun ke depan menjadi konstan atau justru menurun. Oleh karena itu, hasil empiris bagi hipotesis ketiga ini kemungkinan disebabkan oleh perbedaan siklus operasi perusahaan yang menjadi objek penelitian. Dechow et al(1997), menegaskan bahwa laba tetap merupakan item prediktor yang lebih baik mengenai kinerja perusahaan di masa yang akan datang. Penyebabnya ialah bahwa arus kas operasi tahun berjalan memiliki korelasi yang cenderung negatif terhadap arus kas operasi satu tahun kedepan akibat adanya siklus operasi kas. Unsur komponen akrual dalam laba meniadakan (offset) korelasi negatif tersebut sehingga laba cenderung memiliki korelasi negatif yang lebih rendah apabila dibandingkan dengan arus kas operasi tahun berjalan.

Fenomena peningkatan kualitas informasi akuntansi yang terjadi dapat disebabkan oleh pergeseran penggunaan metode penilaian suatu transaksi. Standar yang digunakan sebelum periode konvergensi IFRS menggunakan metode historical cost. Pasca konvergensi IFRS, mayoritas metode penilaian suatu transaksi menggunakan konsep fair value. Sonbay (2010), menyatakan bahwa historical cost cenderung kurang relevan karena adanya time value of money sehingga tidak mencerminkan keadaan sesungguhnya. Laba atau rugi yang terjadi merupakan hasil dari perhitungan yang didasarkan pada stable monetary unit menjadi tidak riil jika diukur dengan perkembangan daya beli uang yang sedang berlangsung. Konsep fair value yang begitu dominan dengan adanya konvergensi IFRS menjadikan kelemahan konsep historical cost menjadi dapat teratasi.

Public interest theory menyatakan bahwa pemerintah beserta agennya memperkenalkan regulasi sebagai bentuk kompensasi bagi market failure. Regulasi hadir demi melindungi kepentingan masyarakat secara keseluruhan. Godfrey et al (2010), menyatakan bahwa kehadiran regulasi dianggap dapat membuat kehidupan masyarakat menjadi lebih baik. Peralihan standar yang dimandatkan oleh pemerintah terbukti mampu memberikan dampak yang signifikan. Perubahan standar yang diinstruksikan oleh pemerintah terbukti secara empiris mampu memberikan kualitas informasi akuntansi yang lebih baik. Peralihan tersebut lebih mampu melindungi pemakainya, dan lebih dapat memenuhi kebutuhan pasar.

Fenomena superioritas kemampuan prediktif laba daripada arus kas operasi pasca konvergensi IFRS dapat dipahami melalui pemaparan berikut. Dechow et al (1997), menegaskan bahwa laba tetap merupakan item prediktor yang lebih baik mengenai kinerja perusahaan di masa yang akan datang. Penyebabnya ialah bahwa arus kas operasi tahun berjalan memiliki korelasi yang cenderung negatif terhadap arus kas operasi satu tahun ke depan akibat adanya siklus operasi kas. Unsur komponen akrual dalam laba meniadakan (offset) korelasi negatif tersebut sehingga laba cenderung memiliki korelasi negatif yang lebih rendah apabila dibandingkan dengan arus kas operasi tahun berjalan. Kim \& Kross (2005), menjelaskan bahwa konsep konservatisme akuntansi bisa jadi memainkan peranan yang penting atas hasil empiris tersebut. Kim \& Kross (2005), menjelaskan bahwa bad news lebih tercermin secara cepat pada laporan keuangan. Lafond \& Roychowdhury (2007), menyatakan bahwa konservartisme akuntansi melibatkan penggunaan standar yang lebih ketat untuk mengakui bad news sebagai kerugian daripada mengakui good news sebagai keuntungan. Dalil ini dapat menjelaskan hubungan antara fenomena superioritas laba tahun berjalan dibandingkan arus kas tahun berjalan dalam memprediksi satu tahun ke depan pasca konvergensi IFRS.

\section{KESIMPULAN}

Penelitian ini berhasil menjawab dua isu krusial dalam akuntansi secara bersamaan. Pertama ialah laba dan arus kas operasi tahun berjalan terbukti memiliki kemampuan untuk 
memprediksi arus kas operasi satu tahun ke depan. Kedua ialah kebijakan konvergensi IFRS terhadap standar pelaporan keuangan terbukti mampu meningkatkan kemampuan prediktif laba dan arus kas operasi terhadap arus kas operasi satu tahun ke depan. Informasi laba terbukti mampu mencerminkan kinerja perusahaan secara lebih komprehensif daripada informasi arus kas operasi. Laba terbukti mampu menjelaskan tidak hanya kinerja perusahaan pada suatu periode, tetapi secara spesifik mampu memprediksi kemampuan perusahaan dalam menghasilkan kas dan setara kas di masa yang akan datang. Temuan ini dapat menjadi referensi bagi para analis keuangan dalam melakukan penilaian terhadap kinerja sebuah perusahaan.

Berbagai hasil penelitian ini perlu dikembangkan lebih lanjut demi memperoleh kesimpulan yang memiliki nilai presisi yang tinggi. Kemampuan prediktif unsur-unsur laporan keuangan ini hanya berlaku pada horizon waktu yang sangat singkat, yakni satu tahun ke depan. Keterbatasan ini menyebabkan kemampuan prediktif yang disimpulkan menjadi kurang optimal dalam mencerminkan kondisi kinerja sebuah perusahaan. Selain itu, demi menguji presisi kemampuan prediktif laba, maka variabel laba dapat diagregasi ke dalam beberapa komponen akrual. Hal ini penting untuk melihat bagaimana setiap komponen laba mempengaruhi kemampuan laba dalam memprediksi arus kas operasi masa depan.

\section{DAFTAR PUSTAKA}

Ball R. 2006. International Financial Reporting Standards (IFRS): Pros and Cons for Investors. Accounting and Business Research,36: 5-27.

Cahyonowati N. and Ratmono D. 2012.Adopsi IFRS dan Relevansi Nilai Informasi Akuntansi.Jurnal Akuntansi dan Keuangan, 14:105-115.

Cheng C. S. and Hollie D. 2005. The Persistence of Cash Flow Components into Future Cash Flows.Diakses 14 Oktober 2015. Available at SSRN: http:// ssrn.com/abstract $=541293$.

Dahler Y. and Febrianto R. 2006. Kemam- puan Prediktif Earnings dan Arus Kas dalam Memprediksi Arus Kas Masa Depan.Simposium Nasional Akuntansi IX. Padang. Diakses 27 Desember 2015. Available from: http://ojs.unud.ac.id/ index.php/ji ab/article/ viewFile/2575/1787.

Daske H., Hail L., Leuz C., and Verdi R. 2008. Mandatory IFRS Reporting Around the World: Early Evidence on the Economic Consequences. ECGIFinance Working Paper No.198/2008.Diakses 14 Oktober 2015. Available from SSRN: http://ssrn.com/ abstract $=1024240$.

Dechow P. M., Kothari S. P., and Watts R. L. 1997. The Relation between Earnings and Cash Flows.Journal of Accounting and Economics, 25: 133-68.

Godfrey J., Hodgson A., Tarca A., Hamilton J., and Holmes S. 2010. Accounting Theory, $7^{\text {th }}$ edition. Australia: Wiley.

Houqe M., Zijl T., Dustan K., and Karim A. 2012. The Effect of IFRS Adoption and Investor Protection on Earnings Quality Around the World. The International Journal of Accounting, 47: 333-355.

Jeanjean T. and Stolowy H. 2008. Do Accounting Standards Matter? An Exploratory Analysis of Earnings Management Before and After IFRS Adoption. Journal of Accounting and Public Policy, 27:480-494.

Joni. 2011. Daya Prediksi Laba dan Aliran Kas (Studi Empiris pada Perusahaan Manufaktur di Bursa Efek Indonesia Periode 2005-2009). Jurnal Review Akuntansi dan Keuangan 1(1): 39-48.

Kim M. and Kross W. 2005. The Ability of Earnings to Predict Future Operating Cash Flows Has Been Increasing - Not Decreasing. Journal of Accounting Research, 43: 5.

Lafond P. and Roychowdhury. 2007. Managerial Ownership and Accounting Conservatism.Journal of Accounting Research, 46:101-135.

Laming R. F. 2014. Pengaruh Konvergensi IFRS terhadap Earnings Management dengan Corporate Governance sebagai 
Variabel Moderasi (Tesis). Makassar: Universitas Hasanuddin.

Lestari and Takada. 2010.Value Relevance of Accounting Information during IFRS Convergence Process in Indonesia.Simposium Nasional Akuntansi XVII.Mataram.Diakses 10 Oktober 2015. Available from: http:// multiparadigma.lecture.ub.ac.id/ files/2014/09/002.pdf.

Nuariyanti N. K. I. and Erawati N. M. A. (2014).Analisis Komparatif Kinerja Perusahaan Sebelum dan Sesudah Konversi ke IFRS.E-Jurnal Akuntansi Universitas Udayana, 274-286.

Petreski M. 2005. The Impact of International Accounting Standards on Firms.Working Paper, School of Business Economics and Management, University American College.

Pigou A. C. 1932. The Economic of Welfare. London: MacMillan.

Pouraghajan A., Emamgholipour M., Niazi F., \& Samakosh A. 2012. Information Content of Earnings and Operating Cash Flows: Evidence from the Tehran Stock Exchange. International Journal of Economics and Finance, 4:7.

Shubita M. F. 2013. The Forecasting Ability of Earnings and Operating Cash Flow.Interdisciplinary Journal of Contemporary Research in Business, 5:3.

Sonbay Y. Y. 2010. Perbandingan Biaya Historis dan Nilai Wajar: Historical Cost versus Fair Value. Kajian Akuntansi, 2 (1):1-8.

Staubus G. J. 1999. The Decision-usefulness Theory of Accounting: A Limited History. New York and London: Garland Publishing, Inc.

Takhtaei N. \& Karimi H. 2013. Relative Ability of Earnings Data and Cash Flow in Predicting Future Cash Flows. International Journal of Accounting and Financial Reporting. 3 (1).

Watson J. \& Wells P. 2005. The Association between Various Earnings and Cash Flow Measures of Firm Performance and Stock Return: Some Australian Evidence. Diakses 10 Oktober 2015. Avail- ablefrom SSRN: http://papers.ssrn.com/ sol3/papers.cfm/abstract id=815365.

Zhao Y., Hobbes G., \& Wright S. 2007. Predicting Future Cash Flow from Operations: Australian Evidence.Diakses 14 Oktober 2015.Available from SSRN: http:// ssrn.com/ abstract=1014865. 